\title{
NEWS
}

\section{Director's Report 2016-2017}

\author{
Sue Hamilton
}

\section{Marking our 80th Anniversary}

The Institute of Archaeology (IoA) reached its 80th Anniversary in 2017. The Institute originated in Mortimer Wheeler's vision, conceived in the 1920s, of creating a centre for archaeological training in Britain. Thanks to his efforts and those of his wife, Tessa Verney Wheeler, the Institute was officially opened in 1937, at St John's Lodge, Regent's Park, with Mortimer Wheeler as its first director. Among its early members of staff were some of the founding ancestors of archaeology in Britain. Today, the Institute is the largest Department of Archaeology in Britain, and one of the largest in the world. The Institute is at the forefront of research and teaching across its three Research Sections in World Archaeology, Archaeological Sciences, and Heritage Studies and has a focus on the importance of the past in the present and for the future.

In August 2017 we renewed a Memorandum of Agreement with the Museum of Emperor Qin Shihuang's Mausoleum, Xi'an in recognition of our ongoing, major joint research project entitled Imperial Logistics of the Terracotta Army project. Now, to commemorate of our $80^{\text {th }}$ anniversary, the Emperor Qin Shihuang's Mausoleum Museum has given the Institute a to-scale replica terracotta warrior. (Further information about this gift can be found in the news section below).

UCL Institute of Archaeology,

London WC1H OPY, UK

ioa-director@ucl.ac.uk
Also in recognition of our anniversary, the Institute's Library is organizing the digitization of all editions of Gordon Childe's influential The Dawn of European Civilisation (Childe was Director of the Institute from 1940-57). (Childe's work and the digitization are discussed in the research article by Katie Meheux below.)

Yet again, we have had an eventful, productive academic year in 2016/17, as reported below.

\section{New Staff and Staff Promotions}

We are delighted that Alice Stevenson (Fig. 1) has been appointed to our new post of Senior Lecturer in Museum Studies. Alice was formally the Curator of the Petrie Museum of Egyptian Archaeology, UCL, and previously Researcher in World Archaeology at the Pitt Rivers Museum. She is a valued addition to the Insitute's Heritage Section that is growing apace in its research and student training, now welcoming more than 70 Masters students annually.

The Institute is also pleased to announce the success of three of its staff in UCL's Senior Staff Promotions, effective from October 2017. These richly deserved promotions acknowledge their research and teaching excellence in their respective fields. Dominic Perring is promoted to Professorial Research Associate; Renata Peters and Dean Sully, are both promoted to Senior Lecturer. We also welcomed a substantial number of new research staff and teaching fellows in 2016/17; they are key contributors to the dynamic environment of the Institute. 


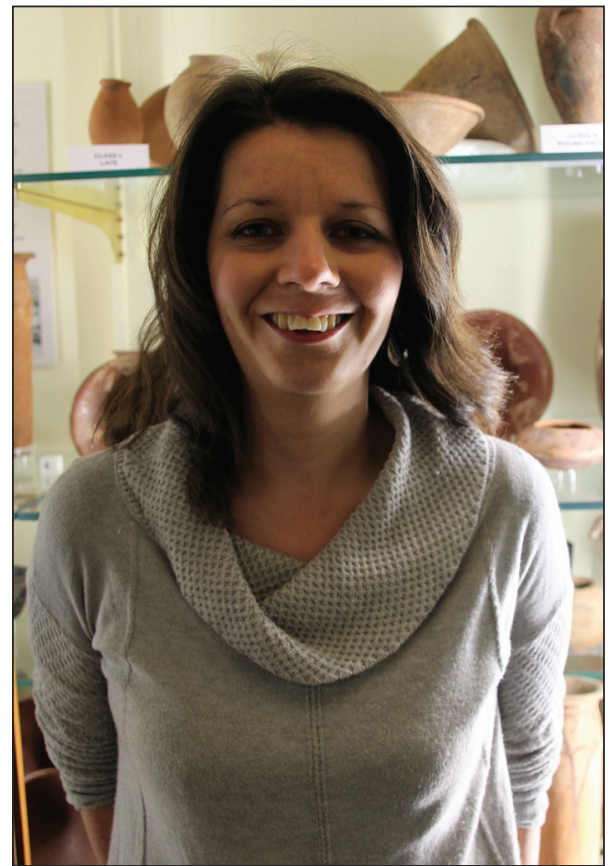

Figure 1: Alice Stevenson (Photo Lisa Daniel).

\section{Awards and Recognition}

Many IoA staff, both individually, and for specific projects, have been recognized via awards and related events through the year.

In December, Sandra Bond was awarded a UCL Sustainability Achievement Award for her work on improving the energy efficiency of IoA laboratories, particularly of our fridge/freezers.

In February, the Ground-truthing Durrington Walls Project, a collaboration between the Stonehenge Riverside Project (led by Mike Parker Pearson), the Stonehenge Hidden Landscapes Project (led by Vince Gaffney) and the National Trust (Nick Snashall), was recognised as Research Project of the Year 2017 at Current Archaeology's 50th-anniversary conference held in London. Mike Parker Pearson was also acclaimed as one of 20 'agenda setting' active archaeologists of 'world renown', to be honoured in the 2017 exhibition Portraits of Archaeologists at Alesia MuseoParc, Burgundy.

In March, Kris Lockyear (Fig. 2) was joint winner of the UCL Provost's Award for

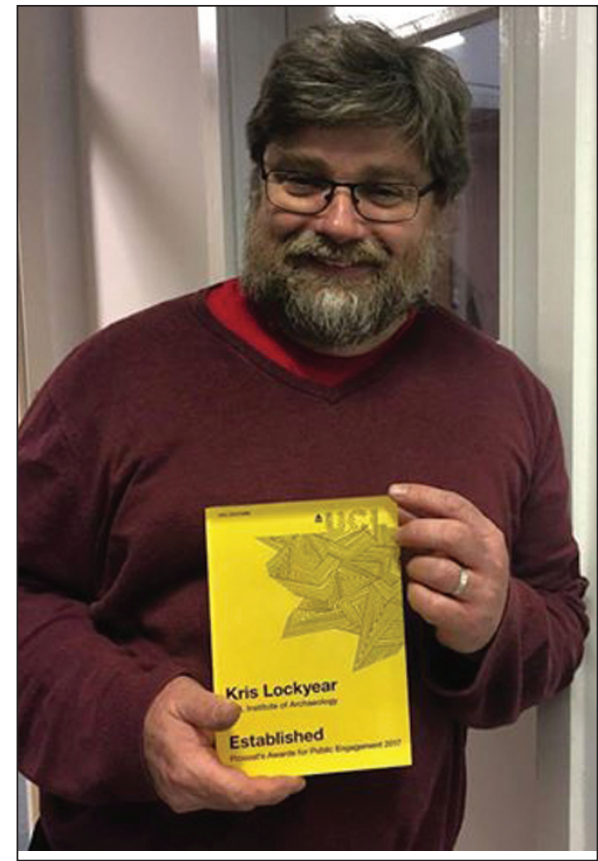

Figure 2: Kris Lockyear, holding his award (Photo Charlotte Frearson).

Public Engagement 2017. Kris has shown enormous dedication to public engagement throughout his career. His leadership in the community programme, 'Revealing Verulamium: Community Heritage, Geophysics and the Archaeology of a Roman Town' made him particularly stand out. Kris Lockyear and Ellen Shlasko had previously presented a Society of Antiquaries public lecture on this ground breaking project.

In April 2017 Elizabeth Graham was honoured with a Lifetime Achievement Award, at the seventh annual Maya at the Lago conference, held in North Carolina, for her 40+ years of archaeological research in Belize (Fig. 3). In May 2017, Ignacio de la Torre was awarded a Chinese Academy of Sciences Visiting Fellowship, which supported a month-long research trip to the Institute of Vertebrate Paleoantology and Paleoanthropology in Beijing, to work on materials from the Nihewan Basin, where some of the earliest stone tools out of Africa have been discovered. 


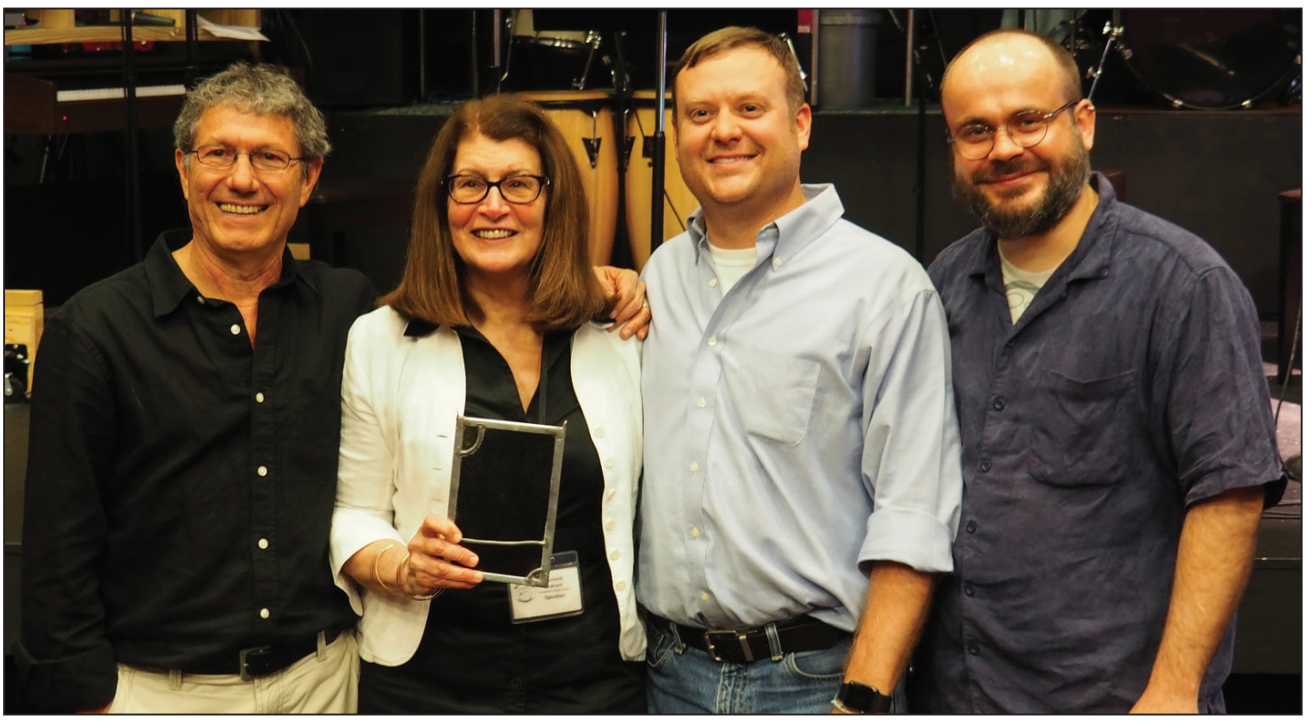

Figure 3: Elizabeth Graham with (l to r) Jaime Awe, former Director, Belize Institute of Archaeology, now N. Arizona University; Mat Saunders, Maya-at-the-Lago convenor; Christophe Helmke, University of Copenhagen (Photo American Foreign Academic Research).

\section{Research Funding Awards}

Several members of staff have had their outstanding international research recognized by external funding; some successes are mentioned below.

In our World Archaeology Section, Corisande Fenwick, in collaboration with Durham University and King's College London $(\mathrm{KCL})$, was awarded funding from the British Council's Cultural Protection Fund in partnership with the UK Government Department for Culture, Media and Sport for the two-year project Training in Action in Libya and Tunisia. The project, led by Anna Leone, (PI, Durham), with Corisande (Co-I) and William Wootton (Co-I, KCL), will train 40 staff from both Libyan and Tunisian national heritage organisations, in documentation, preventive conservation and heritage management.

In our Heritage Studies Section, Rodney Harrison and Trinidad Rico (Director, Cultural Heritage and Preservation Studies, Rutgers University \& Honorary Senior Lecturer, UCL Institute of Archaeology) received an award of $£ 120 \mathrm{~K}$ from the AHRC's Global Challenges Research Fund for the
Restricted Access Pilot Project Interdisciplinary Perspectives on Clean Energy Production and Landscape Conservation in North Patagonia.

In the Archaeological Sciences Section, Dorian Fuller and Charlene Murphy were awarded another analytical grant-in-kind to use the UK's national synchrotron facility (at the Harwell Science and Innovation Campus in Oxfordshire) for the ERC-funded Comparative Pathways to Agriculture Project (ComPag). This aims to provide the first comparative synthesis for the domestication of plants/transition to agriculture at a global level. Diamond Light Source, the UK's synchrotron, harnesses the power of electrons to produce bright light. Using this highly sophisticated technology, the ComPag team are for the first time documenting the rate of evolution of seed coat thinning, a major marker of crop domestication, from archaeological remains.

\section{Recognition and Esteem}

IoA staff regularly gain recognition by major international institutions and research bodies. This year, for example, Stephen Shennan 
was invited to join the International Scientific Advisory Board of the Max Planck Institute for the Science of Human History in Jena due to his outstanding contribution to the development of evolutionary approaches in archaeology.

In September 2016, Tim Williams gave an invited lecture at the British Academy, sponsored by the British Institute at Ankara, on Archaeological Heritage Management: Along the Silk Roads in the $21^{\text {st }}$ Century. Tim highlighted how the conflicting interests in the stewardship, and value and use of archaeological research, conservation, identity building, and tourism, need to be addressed.

In March 2107 Marcos Martinón-Torres was invited to present his ground breaking research in the manufacture and use of Pre-Hispanic goldwork at the Colombian Consulate and, in May, Stephen Quirke was invited to speak at the Egyptian Bureau for Cultural \& Educational Affairs in London. His lecture was entitled Village and Palace: finding ancient Egyptian society in its objects.

\section{Special Events}

The Institute leads, initiates and hosts numerous events on many aspects of archaeology, and we link with other heritage institutions and organizations to provide an outstanding research environment for staff, students and visitors. A small selection of such events over the past year are highlighted below.

\section{September 2016}

Dorian Fuller, by invitation, participated in the New Scientist Live Event in London to discuss The seeds of civilisation. The invention of farming marks one of the most significant turning points in human history and Dorian provided an interpretation of the evidence.

\section{November 2016}

A one-day conference What is Critical Heritage Studies? marked the launch of the joint UCL-University of Gothenburg Centre for Critical Heritage: a collaborative, international, interdisciplinary research centre, which at UCL is based at the Institute of Advanced Studies, with the Institute of Archaeology as the lead department.

The Third Neolithic and Early Bronze Age Research Student Symposium was held at the Institute. This annual symposium showcases new research by postgraduate and early career researchers and its implications for social change during the Neolithic and Early Bronze Age in the UK and beyond.

Hang Kan (Director of the School for Archaeology and Museology, Peking University) gave the Institute's ICCHA Special Guest Lecture 2016 on Buddhism Archaeology in China. The International Centre for Chinese Heritage and Archaeology (ICCHA), is a joint association between the School for Archaeology and Museology, Peking University and the Institute of Archaeology, tasked with bringing China's cultural past to western scholars.

Maria Filomena Guerra (Centre National de la Recherche Scientifique, Université Panthéon Sorbonne) gave the high profile Beno Rothenberg Memorial Lecture, 2016 at the Institute, entitled Gold working reconsidered: a laboratory perspective. This annual event is organised by the Institute for Archaeo-Metallurgical Studies, which is affiliated to the Institute.

\section{December 2016}

The conference Climate Change, Archaeology and History (organised by Miguel Fuentes, Institute research student and Francisco Diego, Senior Research Fellow, UCL Department of Physics and Astronomy) was held over two days at the Institute and explored the possible 'collapse of civilization', using a multidisciplinary framework.

\section{January 2017}

The Third Islamic Archaeology Day, jointly hosted by SOAS (the School of Oriental and African Studies, London) and the Institute, brought together papers on the latest archaeological research across the Islamic 
world. In February this was followed by the Institute conference The Origins of the Islamic State: Sovereignty and Power in the Middle Ages. The event, organized by Corisande Fenwick, was supported by the British Academy Rising Star Engagement Award received by Corisande in 2016. The award was for engagement activities to address the significant challenges facing those studying the archaeology and history of the Islamic world, in the wake of the contemporary advance of the Islamic State group. A subsequent workshop in March, was hosted by the Institute and the UCL Institute of Advanced Studies, which explored aspects of the development of the earliest Islamic states.

\section{March 2017}

The Third Annual UCL Lecture on Climate and Human History was sponsored by the UCL Past Climates Group, Department of Geography, and the Institute's Archaeological Sciences Section. Eske Willerslev (University of Cambridge/University of Copenhagen), gave the presentation Ancient DNA and the rewriting of our human history.

A special event to mark the publication of Collecting, Ordering, Governing: Anthropology, Museums and Liberal Government (Duke University Press), co-authored by Rodney Harrison, was held at the UCL Grant Museum of Zoology. The book is the outcome of collaborative Australian Research Council-funded research exploring relationships between anthropological fieldwork, museum collecting and display, and social governance in early twentieth-century Australia, Britain, France, New Zealand, and the United States.

\section{May 2017}

The Institute hosted a UNESCO/UCL expert workshop on the serial nomination of the Maritime Silk Routes, organised by Tim Williams. This provided for dialogue between the State Parties along the routes, encompassing experts from Japan, Republic of Korea, China, Philippines, Indonesia, Thailand, Singapore, Sri Lanka, Iran, Abu Dhabi, Oman, and Tanzania and international scholars from Australia, Canada, France, and the UK.

This year's prestigious Institute of Archaeology's Annual Gordon Childe Lecture was given by Patricia A. McAnany (University of North Carolina). Her lecture, entitled Experimental by Design: Rethinking Political Solution and Dissolution in the Maya Lowlands was followed the next day by the Gordon Childe Seminar (organised by Manuel Arroyo-Kalin) in which Professor McAnany and Institute staff participated in an extended debate on Archaeology and Heritage: Clashes and Compatibilities.

The very popular Institute of Archaeology Annual Conference 2017, was also held in May, organised by Carolyn Rando and Marija Edinborough. The subject was Stressed Out! Debunking the stress myth in the study of archaeological human remains (further information can be found below).

Towards the end of May the Institute community reflected on the developing 'Brexit' situation, aiming to shape an agenda for action. A one-day workshop Brexit, Archaeology and Heritage: Reflections and Agendas was organised by Andrew Gardner and Rodney Harrison. This was intended to inaugurate a future series that will explore themes relating to the practical impacts of Brexit on the lives and interactions of those working in archaeology and heritage, and issues of heritage and identity in the UK, Europe and beyond.

May ended with Rodney Harrison's Inaugural Lecture as Professor of Heritage Studies entitled Heritage Futures and Future Heritages. Rodney's far-reaching lecture explored 'how taking a comparative approach to understanding natural and cultural heritage conservation practices, and bringing heritage, broadly defined, into conversation with the management of other material and virtual legacies such as nuclear waste, might help transform our understanding of the work that 
heritage and other conservation practices do in society.'

\section{June 2017}

Institute of Archaeology staff, working with other UK universities, created the first University Archaeology Day aimed at inspiring the next generation of archaeologists. The event (initiated and co-organised by Andrew Gardner and Charlotte Frearson) was hosted by UCL (further information can be found below).

\section{International Conferences}

Throughout the year, our staff and students maintained a strong profile at international conferences. Highlights include:

In April, under the leadership of Rhiannon Stevens, the Institute hosted the UK Archaeological Science Conference; a biennial international conference that brings together researchers from all areas of archaeological science. Institute research student Laura Ware Adlington was awarded the UKAS Student Presentation prize for her paper entitled The life history of the Ancestors of Christ from Canterbury Cathedral: An investigation of medieval stained glass window production by handheld $p X R F$.

The Institute's outstanding research and extensive collaborative links were highlighted, at the Society for American Archaeology's 82nd Annual Meeting, held in Vancouver in March. More than 30 Insitute staff and students contributed to or presented papers.

Throughout the year, a number of staff were inivited to give prestigous keynote lectures. Todd Whitelaw gave the keynote lecture entitled Reconciling objectives and methods in the collection and analysis of surface survey ceramics in Greek surveys at a European inter-insitutional conference for early career researchers on Recording and Interpreting Survey Ceramics, hosted at the Danish Institute, Athens.

Stephen Shennan was invited to be keynote speaker at the Third Central European
TAG conference which took place in Slovakia at the Department of Archaeology, Comenius University, Bratislava, with a lecture entitled 'Neo-Culture History': Using the Insights of Cultural Evolution to Take a Fresh Look at Culture History.

\section{Recognition of Teaching and Student Support}

Congratulations to the Institute staff who were recognised for their outstanding contribution to the learning experience and success of UCL students in the UCLU Student Choice Teaching Awards 2017. Forty-two Institute staff and Teaching Assistants were nominated across the various categories for their commitment to excellence. Judy Medrington received an award for Outstanding Personal Support, which celebrates excellence in student guidance and pastoral care. This is the fourth time that Judy has received this award!

\section{Delegations, Official Visits and Memoranda of Understanding} It has been a pleasure through 2016/17 for the Institute to host a number of delegations and official visitors. In particular, the Institute continues to maintain and develop strong contacts with notable Chinese Institutions. In November 2016, during a visit to the Institute, a MOU was signed between the Institute of Archaeology and the Administration Committee of Liangzhu (ACL), the direct governing body for cultural heritage management and conservation of cultural relics for the Liangzhu District, Zhejiang Province, China, one of the most important site areas of the Neolithic in the lower reaches of the Yangtze. The planned collaboration includes staff training and exchange, and joint publications on the archaeological and cultural heritage research of the Liangzhu site area.

Our major connection with Peking University (PKU) is ongoing. In December we came together at the Institute to plan a joint conference, Materialising Empires, to be held at PKU, Beijing in Spring 2018. 


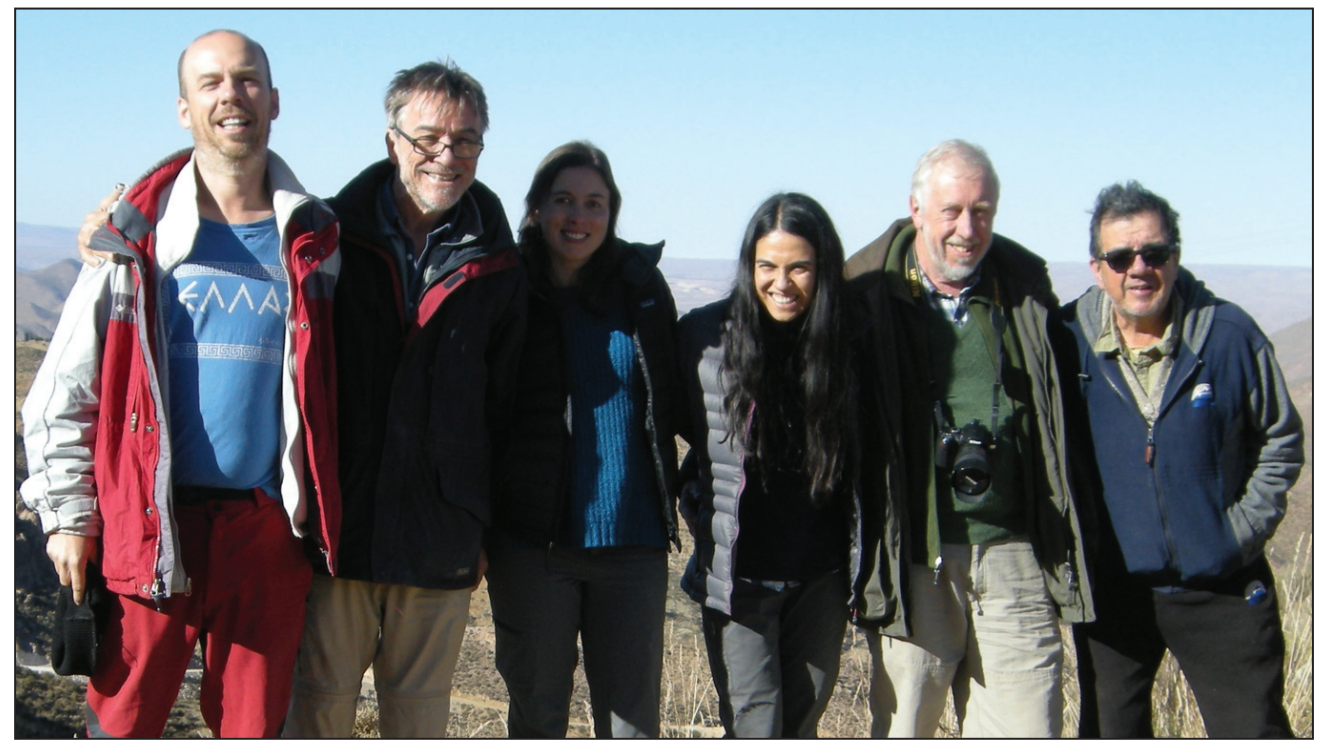

Figure 4: James Steele (second left) with colleagues from IoA and Instituto de Alta Investigación, Universidad de Tarapacá, Chile (Photo James Steele).

Further new formal collaborations include one between the Competence Center Archeometry-Baden Wuerttemberg (University of Tübingen) and the Institute's Ceramic Technology Research Network (lead Patrick Quinn), and an agreement of collaboration with Instituto de Alta Investigación, Universidad de Tarapacá, Chile (lead James Steele) (Fig. 4). In recent years, the Institute has received a number of Masters and research students from Chilean institutions and we will be building on these contacts.

\section{Lectures, Exhibitions and}

\section{Engagement}

Marcos Martinón-Torres and Patrick Quinn visited Singapore in the Autumn, together with Dr Zhang Weiling from the First Emperor's Mausoleum Site Museum, Xi'an, and presented their research on the Terracotta Army in public talks at the Lien Fung's Colloquium, organised by Singapore Management University. The event attracted over 400 people.

In February Sue Hamilton and Amara Thornton participated in a special educational outreach event at the Society of
Antiquaries, London. Organised by Rebecca Wragg Sykes (TrowelBlazers) and Leonora Saunders (Photographer, Raising Horizons exhibition), a group of female students from the Harris Academy Bermondsey visited the Raising Horizons exhibition (which featured several female professional archaeologists associated with the Institute) at the Geological Society, then participated in a unique learning experience hosted by the Society of Antiquaries. The students presented Come Dig With Me: An Adventure into the Forgotten Archaeological, Paleontological and Geological Herstory to their peers followed by $1: 1$ discussion with the trowel-blazing professionals including Amara and Sue, who talked about their paths into their fields. In a similar vein, Carolyn Rando was invited to participate in the inaugural Inspiring Women in Science event at the Royal Society in May, (Fig. 5) which aims to encourage female role models to visit local schools to inspire the next generation of scientists.

Exemplifying the wider outreach of Institute research is the AHRC-funded Heritage Futures project, led by Rodney Harrison, which is currently advising 


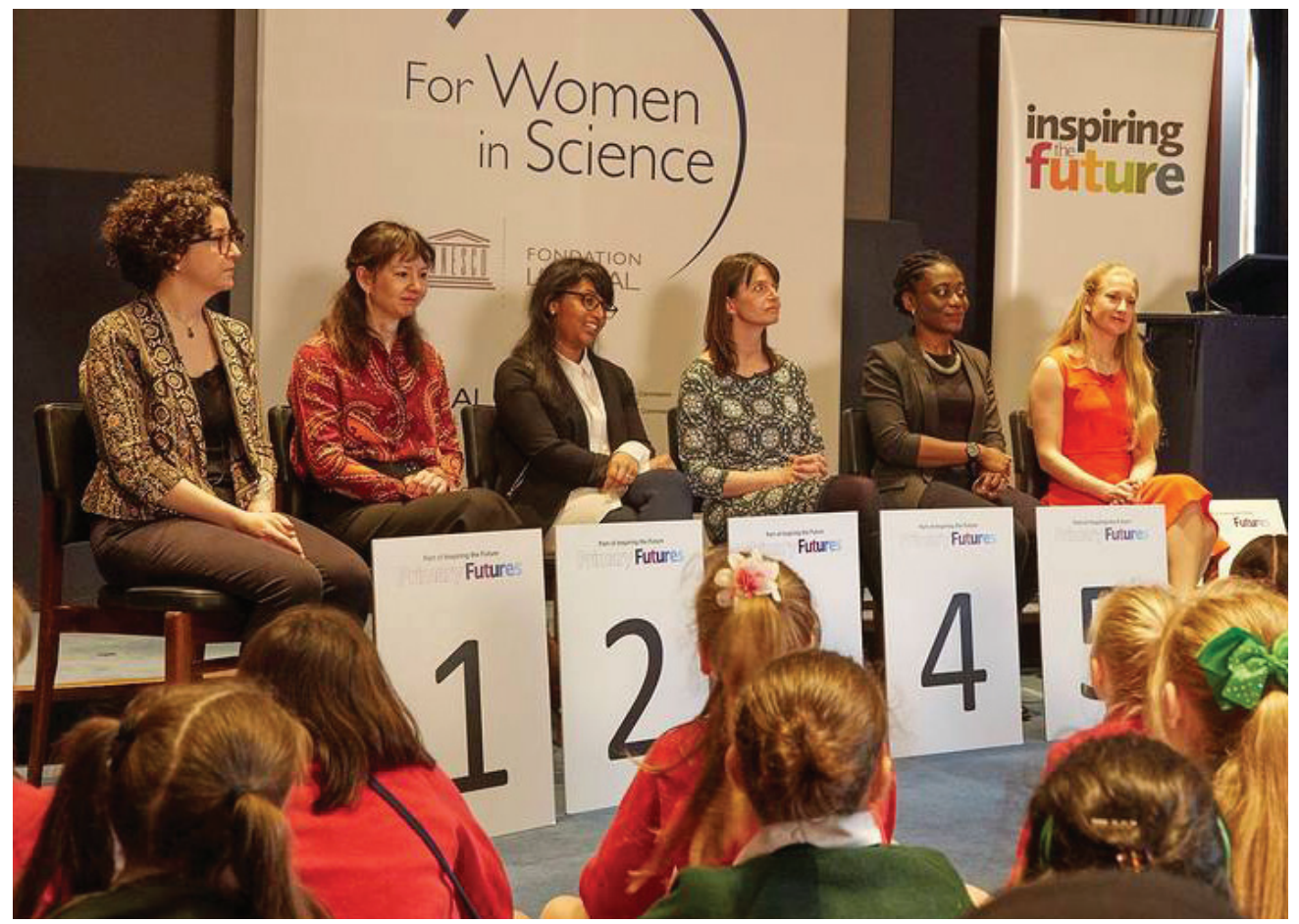

Figure 5: Carolyn Rando (on left) at the Inspiring Women in Science event (Photo The Education and Employers Taskforce).

Austrian ceramicist Martin Kunze on what information to include for his high publicity project to bury a snapshot of all human knowledge. Martin has spent the last four years engraving images and text onto handsized clay plates that will be buried in the world's oldest salt mine in Hallstatt, Austria. The Heritage Futures and AHRC Heritage Priority Area teams (led by Rodney Harrison) will also be collaborating with BeatFreeks Arts, who have been awarded $£ 696,700$ to run the Radical Heritage Project (RHP) as part of The Heritage Lottery fund's $£ 10$ million Kick the Dust fund.

In June, the exhibition Los ecos del Proyecto Huemul, 1949-2017, part of the AHRC-Global Challenges Research Fund Restricted Access Pilot Project, led by Trinidad Rico (Rutgers University \& Honorary Senior Lecturer, UCL Institute of Archaeology) and Rodney Harrison, opened at the Balseiro Institute in San Carlos de Bariloche, Argentina, the most prestigious nuclear engineering and experimental physics research and teaching centre in Latin America. The exhibition explores interdisciplinary perspectives on clean energy production and landscape conservation via the 'echoes' and 'afterlives' of the Huemul Atomic Project.

The annual World Archaeology Festival took place in June 2017 and was dedicated to the $80^{\text {th }}$ anniversary of the Institute. The event formed the Institute's contribution to the Council of British Archaeology's Festival of Archaeology and, as usual, there were talks and activities for all ages and interests. This year, it featured in UCL's inaugural It's All Academic Festival; a celebration of all that is great at UCL. As part of the latter, Jonathan Gardner gave a walking tour of the Queen Elizabeth Olympic Park in Stratford, East London to showcase the archaeology and heritage of the site, including the sites proposed for UCL East, a major new expansion of the UCL outside of Bloomsbury, where the Institute will be involved in 


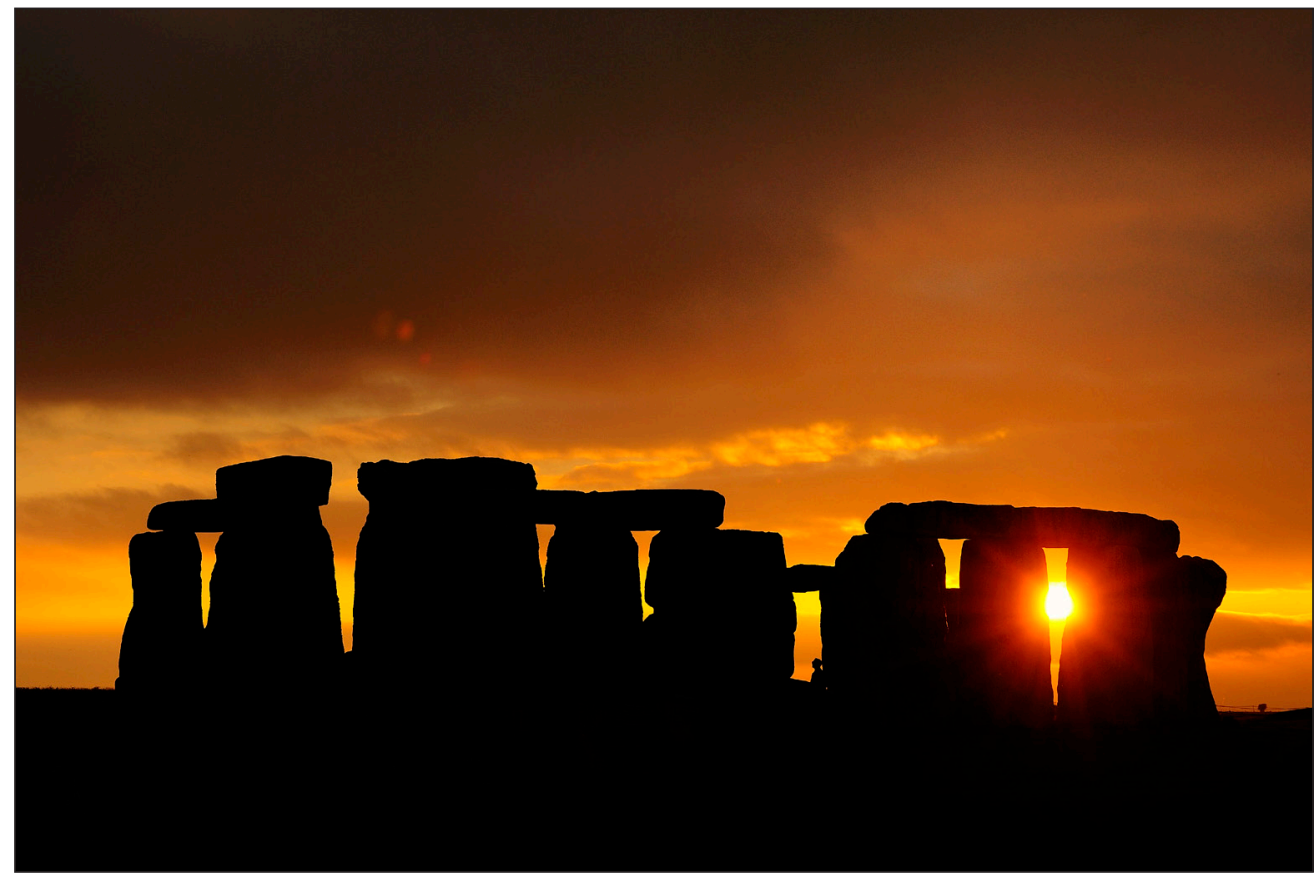

Figure 6: Sunset at Stonehenge (Photo Adam Stanford, Aerial-Cam Ltd).

heritage initiatives, as part of an inter-faculty collaboration.

The Institute's MA Museums Studies student exhibition, Sex and Symbolism, which uses art, archaeology, and modern material culture to explore how seduction, sensuality, and sex have been represented through time, opened to the public for a year in May 2017 and is displayed within our A.G. Leventis Gallery of Cypriot and Eastern Mediterranean Archaeology.

The Institute's leadership in Stonehenge initiatives, revealing its past and influencing its future remains strong and ongoing. In March 2017 Mike Parker Pearson led a consortium of 21 eminent archaeologists who argued that a government proposal to construct a tunnel under Stonehenge would block the sunset view the monument was designed to capture (Fig. 6).

\section{News of Former Staff and Friends}

Clive Orton, Emeritus Professor of Quantitative Archaeology at the Institute, has recently published his memoirs Degrees of Freedom: and other episodes in an archaeological life. Clive continues to take an active part in the Institute community, serving the Institute's Publications Committee, and he is Editor Emeritus of the London Archaeologist. Another year also brings sadnesses. We were sorry to have to report the sudden death of Jan Porter who joined us in 2000 as a mature student to study the BSc Archaeology. We were also saddened to hear of the deaths of several Institute alumni and friends: Bridget Allchin, Dai Morgan Evans, Ke Jun, Geoff Wainwright, Cecilia Western and John Wilkins (see brief obituaries below).

\section{Concluding remarks: into the future}

The Institute of Archaeology continues to thrive. At our Bloomsbury base alone in 2016/17 we together totalled over 100 Academic Staff, Teaching Fellows, and postdoctoral Research Staff, together with c. 650 students. For 2017/18, we are looking forward to new appointments and positions in Archaeological Sciences, Heritage Studies, and World Archaeology. New areas of focus and 
deepening innovation and coverage include teaching and research on the Islamic World, the Americas (e.g. Amazonia), Future Heritages, Isotope Analysis Methodologies, Technology and Materials, Human Plant and Animal Use and Human Evolution. Our Essex and Sussex based Centre of Applied Archaeology, which includes the commercial unit Archaeology Southeast, of around 120 staff, works in the UK and is further extending its International Heritage work, notably in China and on the Silk Roads. Last, but definitely not least, we have an exceptionally committed support staff and technical staff, who have worked excellently and with great committment throughout a particularly busy year, to keep the Institute functioning.

This will be the last edition of Archaeology International edited by Elizabeth Pye. The team who have worked with her over the past three years: Chiara Bonnachi, Charlene Murphy, and Carolyn Rando handed over this year to Jenni French, Barney Harris and Alice Stevenson. We are very grateful to all of them for their commitment in creating such a great product over the past four years. The associated compilation of the annual 'Director's Report', for Archaeology International is a very enjoyable aspect of being Director. The Institute of Archaeology is a special, exciting and ever changing institution and it is certainly challenging and rewarding to capture all that has happened in the past year.

\section{Note}

Furtherdetails ofthenews mentionedherecan be found by searching the Institute's website at http://www.ucl.ac.uk/archaeology/ calendar/news.

How to cite this article: Hamilton, S 2017 Director's Report 2016-2017. Archaeology International, No. 20: pp. 3-12, DOl: https://doi.org/10.5334/ai-366

Published: 14 December 2017

Copyright: (c) 2017 The Author(s). This is an open-access article distributed under the terms of the Creative Commons Attribution 4.0 International License (CC-BY 4.0), which permits unrestricted use, distribution, and reproduction in any medium, provided the original author and source are credited. See http://creativecommons.org/licenses/by/4.0/.

]u[ Archaeology International is a peer-reviewed open access journal published by Ubiquity Press. 